\title{
KNOWLEDGE CITIES: A TAXONOMY FOR ANALYZING SOFTWARE AND INFORMATION SERVICE CLUSTERS
}

\author{
CIDADES DO CONHECIMENTO: UMA TAXONOMIA PARA ANALISAR CLUSTERS DE SOFTWARE E SERVIÇOS \\ CIUDADES DEL CONOCIMIENTO: UNA TAXONOMÍA PARA ANALIZAR CLUSTER DE SOFTWARE Y SEVICIOS
}

\begin{abstract}
Software and information services (SIS) have become a field of increasing opportunities for international trade due to the worldwide diffusion of a combination of technological and organizational innovations. In several regions, the software industry is organized in clusters, usually referred to as "knowledge cities" because of the growing importance of knowledgeintensive services in their economy. This paper has two primary objectives. First, it raises three major questions related to the attractiveness of different cities in Argentina and Brazil for hosting software companies and to their impact on local development. Second, a new taxonomy is proposed for grouping clusters according to their dominant business segment, ownership pattern and scope of operations. The purpose of this taxonomy is to encourage further studies and provide an exploratory analytical tool for analyzing software clusters.
\end{abstract}

KEYWORDS Software and information service clusters, knowledge cities, Brazil, Argentina, industrial and technology policies.

Paulo Bastos Tigre pbtigre@gmail.com Professor at Instituto de Economia, Universidade Federal do Rio de Janeiro - Rio de Janeiro - RJ, Brazil

Renata Lebre La Rovere relarovere@gmail.com Professor at Instituto de Economia, Universidade Federal do Rio de Janeiro - Rio de Janeiro - RJ, Brazil

\section{Francisco Lima Teixeira teixeira@ufba.br Professor at Escola de Administração, Universidade Federal da Bahia - Salvador - BA, Brazil}

Andrés López anlopez@fund-cenit.org.ar Director at Fundación Centro Nacional de Innovación Tecnológica - Buenos Aires, Argentina
Daniela Ramos danielaramos@fund-cenit.org.ar Researcher at Fundación Centro Nacional de Innovación Tecnológica - Buenos Aires, Argentina

\section{Néstor Bercovich nestor.bercovich@cepal.org Economist at Comisión Económica para América La- tina, United Nations Organization - Santiago, Chile}

\section{Alessandro de Orlando Maia Pinheiro \\ alessandropinheiro@ibge.gov.br \\ Economist at Instituto Brasileiro de Geografia e Estatística and doctoral student at Instituto de Economia, Universidade Federal do Rio de Janeiro - Rio de Janeiro - RJ, Brazil}

Silvio Araújo suander@ufba.br
Doctoral Student at Instituto de Administração, Universidade Federal da Bahia - Salvador - BA, Brazil

\section{Ricardo Furtado Rodrigues \\ riccardo.rio@gmail.com \\ Researcher at Grupo de Economia da Inovação do Instituto de Economia, Universidade Federal do Rio de Janeiro - Rio de Janeiro, RJ, Brazil. Doctoral Student at Departamento de Engenharia de Produção, Universidade Federal de Santa Catarina - Florianópolis - SC, Brazil}

Submitted 30.03.2010. Approved 21.09.2010 Evaluated in a double blind review Scientific Editor: Eduardo Diniz, Marlei Pozzebon and Nicolau Reinhard

RESUMO A indústria de software e serviços de informação vem ganhando crescente importância no comércio internacional, graças à difusão de inovações tecnológicas combinadas a mudanças organizacionais. Em muitas regiões tal indústria é organizada em clusters apelidados de "cidades do conhecimento" em função da crescente importância de serviços intensivos em tecnologia em sua economia. Este artigo tem dois objetivos. Primeiro, ele levanta três questões chaves relativas à atratividade de diferentes cidades na Argentina e no Brasil para empresas de software e seus impactos no desenvolvimento local. Segundo, é proposta uma nova taxonomia com o objetivo de agrupar clusters de acordo com o segmento dominante de negócios, origem do capital e escopo de operações. O propósito da nova taxonomia é oferecer uma ferramenta analítica exploratória para analisar clusters de software.

PALAVRAS-CHAVE Clusters de software e serviços da informação, cidades do conhecimento, Brasil, Argentina, políticas industriais e tecnológicas.

RESUMEN En el área de software y servicios de la información (SSI) se han incrementado las oportunidades para el comercio internacional gracias a la difusión mundial de innovaciones tanto tecnológicas como organizacionales. En algunas regiones, la industria del software está organizada en clusters, comúnmente conocidos como "ciudad del conocimiento", a raíz del crecimiento de la importancia de los servicios intensivos en conocimiento en esas economías. El presente trabajo tiene dos objetivos principales. En primer lugar, plantear tres grandes preguntas relacionadas con el atractivo de diferentes ciudades en Argentina y Brasil para el alojamiento de compañías de software y su impacto en el desarrollo local. En segundo lugar, una nueva taxonomía es presentada para agrupar clusters acorde a su segmento dominante de negocios, esquema de propiedad y alcance de sus operaciones. El propósito de esta taxonomía es alentar posteriores estudios y proveer una herramienta analítica exploratoria para analizar clusters de software.

PALABRAS CLAVE Clusters de software y servicios de la información, ciudades del conocimiento, Brasil, Argentina, políticas industriales y tecnológicas. 


\section{INTRODUCTION}

Software and information services (SIS) are viewed as important activities for regional development because they provide opportunities for creating qualified jobs, developing local technological capabilities and producing positive externalities by strengthening user-producer relationships (TIGRE and MARQUES, 2009). In several regions, this activity is organized in clusters, because of the systemic characteristics of the information technology (IT) industry (MEYER-STAMER, 2004).

This paper has two primary objectives. The first is to discuss three major questions related to the attractiveness of different cities in Argentina and Brazil for hosting software companies and their ensuing impact on local development. These issues are often discussed in studies that link information technology and geography, but focusing on hardware rather than software. Ernst (2002), for example, provides good insights on IT value chains and clusters in global production networks in East Asian electronics. The software market in Latin America has been studied by Chudnovsky and Lopez (2005); López and Ramos (2007, 2008, 2009); Tigre (1999, 2003) and Tigre and Marques $(2008,2009)$, among others.

The first of these questions deals with the driving forces behind locational decisions of SIS firms. Archibugi and Iammarino (2001) argue that the globalization of technology and new public policies open several opportunities for decentralization of knowledge production. It should be noted, however, that several cities have developed regional policies to attract SIS companies, but few have effectively succeeded. Therefore, it is important to identify the critical factors determining locational decisions of large information technology (IT) companies and to what extent pre-existing IT clusters have a positive influence on those decisions. Given the intangible nature of SIS activities, what are the elements that determine the attractiveness of a region to SIS firms?

Secondly, we will look at the network effects among large and small firms, universities and research centers. We assume that the mere presence or establishment of IT corporations do not necessarily guarantee positive results in terms of knowledge diffusion and productivity gains in local production. Taking network effects into account, do SIS firms generate knowledge spillovers to the region where they are located?

Thirdly, we will examine the challenges and opportunities for development, using employment generation as the main indicator. It is often assumed that IT investments per se have a major impact on local development, mainly by creating highly qualified jobs. Can technology-intensive activities create a strong demand for better qualified workers?

The second objective is to develop a new methodological approach to the study of an industry which is essentially intangible. Although there are several satisfactory classifications and taxonomies to analyze industrial clusters, literature is poor in appropriate tools to analyze SIS clusters. Therefore, we propose a new exploratory taxonomy that groups clusters according to their dominant business segment, ownership pattern and scope of operations. We believe that this taxonomy can be useful for public policy, not only to understand what kind of clusters can be promoted in each situation, based on available resources, but also what benefits can be expected $a$ priori in each case.

The case studies developed in the original research project attempt to answer these questions, given the fact that clusters may assume different forms and their performance depends on the region's specific set of resources. Specifically, we recognize the importance of specialization economies to local development by focusing the case selection on cities that presented a growing share of employment in software (such as Hortolândia), where an explicit public policy to develop software activities exists (such as Salvador) or where successful software clusters were already identified by existing literature (such as Blumenau and Rosario, Argentina). Also, given the fact that the locational decisions of companies are also affected by the region's specific set of resources, we studied cities that have successful technological poles linked to software development: Porto Alegre (Tecnopuc) and Recife (Porto Digital).

Our main findings are presented in Section "Main findings of the research", which provides clues to the three questions raised above. We found that cities that are able to attract SIS firms present a combination of highly skilled workers, good local universities and a friendly institutional environment, with local governments that actively seek to develop the industry. However, the attraction of SIS firms does not necessarily guarantee knowledge flows, given that the transmission of technology to local firms depends on relations between different agents. Therefore, the perspectives for regional development depend essentially on local institutional arrangements.

The research methodology was developed during a research program sponsored by the International Development Research Council of Canada (IDRC) on knowledge economy in Latin America, which selected four projects out of 248 submitted in 2006. Our project is based on comparative studies undertaken by six re- 
search teams, led by experienced academics from both Argentina and Brazil, which incorporated a common view about concepts, analysis variables, research objectives and case selection. Each team conducted one or two case studies based on common questions for undertaking semi-structured interviews with IT companies, research institutions and local government authorities. The questions that guided the research were designed in three seminars involving both authors and invited experts to review and discuss the relevant literature and develop methodological approaches. Its outcome was the book Outsourcing and Software Clusters in Argentina and Brazil (TIGRE and others, 2009).

The research identified some similarities in ownership patterns (local or foreign), market segments targeted by the companies and geographical scope of operations. By linking these categories to the strategies and institutional arrangements of the companies, we propose a taxonomy of software clusters (presented in section "Proposed taxonomy of software clusters") that allows a differentiation of clusters according to specific combinations of resources, markets, technologies and companies. Therefore, we propose grouping clusters as (i) Outsourcing Platforms, (ii) Technology Clusters, and (iii) User-Producer Networks. The goal of this taxonomy is to encourage further studies and provide an analytical tool to understand the dynamics of software clusters and their links with the territory. Finally, the fifth and final section of this paper presents a summary of the main findings.

\section{A REVIEW OF THEORY: BUSINESS CLUSTERS IN THE SIS INDUSTRY}

Literature on business clusters in a given territory is usually related to the manufacturing sector, where industrial agglomerations create, more often than not, positive externalities by linking upstream and downstream partners. In the SIS industry, however, these benefits have yet to be demonstrated, given the intangible nature of its products and services. Because information goods can be processed, stored, distributed and consumed wherever technical capabilities are available, the location of software and information services is becoming less attached to traditional factors such as the existence of other complementary businesses.

In addition, the production chain of the SIS industry is very short, which leaves few opportunities for backwards integration. This is because corporations tend to focus on their core competencies and outsource operations to specialized providers. These developments encourage the splitting of the production processes of many services into discrete components, some of which can be "downloadable" and processed by pockets of skilled specialists in less developed or intermediate countries (MIOZZO and MILES, 2002).

Despite the specifics of the SIS industry, the existing literature on industrial clusters is a good start for an analysis of their impact because of the discussion of externalities. For Paci and Usai (2000), cluster externalities are related to effects on production and technology. Productionrelated externalities are either location externalities that allow the sharing of a common infrastructure, or pecuniary externalities resulting from the benefits obtained with the sharing of primary and intermediate goods and pooling of labor force. Technology-related externalities result from technology sharing and can be divided into diversity economies and specialization economies. Specialization economies occur when the formation of the cluster allows the sharing and circulation of information and knowledge. This sharing sets the basis for cumulative learning processes, advances in knowledge and development of innovation. Diversity economies occur when the milieu of the territory has several types of information and knowledge flows, stimulating creativity and sharing of production principles which are not necessarily linked to the same technologies or industries. Some large urban agglomerations have this type of externalities that is known among specialists as Jacobs externalities.

Glaeser and others (1992) made an important contribution to the discussion of technology-related externalities by identifying three possible effects of these externalities on the growth of cities. The first two possible effects are related to economies of specialization, while the third is related to diversity economies. The first, known as the Marshall-Arrow-Romer (MAR) externality, occurs when the concentration of industries helps knowledge spillovers between firms in an industry and the local growth of that industry. The internalization of MAR externalities leads to local monopolies of knowledge which explain the growth in the local industry. The second effect is known as Porter externality, and also results from knowledge spillovers between firms. The difference between Porter externalities and MAR externalities is that Porter considers in his work that knowledge spillovers are positive for regional growth, not because they lead to local monopolies of knowledge, but rather because they increase competition between firms and it is this process that will encourage firms to develop innovations. The third effect is Jacobs externalities, which are linked to the fact that diversity in a milieu 
fosters creativity and therefore generates new ideas that lead to innovation (GLAESER and others, 1992).

As observed by Desrochers and Hospers (2007), the diffusion of Jane Jacobs' ideas among economists increased after Glaeser and others, (1992) suggested in their paper that Jacobs externalities were more important for the growth of cities than MAR and Porter externalities, based on empirical data from the U.S. Their work opened a debate among specialists that have been trying to validate this proposition for the U.S. and other economies as well (see PANNE, 2004).

The existence of these different externalities has implications for understanding policies in support of clusters. If Jacobs externalities are indeed important for the growth of the cities, medium-sized cities should always try to diversify their industrial basis. However, if the prevalence of Jacobs externalities on growth is not confirmed, an option for policymakers from those cities is to try to counterbalance possible disadvantages related to the lack of diversity by promoting specialization. Regardless of whether they lead to local monopolies or not, the fact is that specialization economies also have positive effects on knowledge spillovers and local innovation. As the promotion of clusters involves the coordination of several policies, local institutions go through a learning process on the best policy options as they implement them (ROVERE, HASENCLEVER and ERBER, 2004).

If local institutions are promoting growth through regional specialization, two facts have to be taken into consideration. The first is that clusters may assume different forms. They may assume a hub-and-spoke configuration, with several small firms providing products and services to a large firm, or they may be a collection of firms integrated in a network, as in the case of Italian industrial districts. Clusters may also be created around technological poles or by spin-offs of local universities. Thus policymakers have, in the promotion of clusters, two options to promote regional development: granting subsidies to attract a large firm that will act as hub, or promoting networks of firms by fostering Italian-style industrial districts, or technological poles.

The second fact that must be considered is that the locational decisions of firms not only influenced by public policy but also depend on the attractiveness of the region, which is linked to its specific set of (institutional, social and human) resources. In the case of SIS, the most important resources are linked to the region's ability to produce knowledge. Continuous technological and organizational innovations are creating Schumpeterian-type opportunities for reshaping the global distribution of labor in information services. As a result, competitive companies specializing in the provision of outsourced services are allocating some of their functions to foreign-based affiliates set up in order to take advantage of locational benefits, particularly in the areas of human resource costs and skills, and integrating them through intra-firm trade (ZIMMY and MALLAMPALLY, 2002). Cohendet and Joly (2001) reinforce this view by arguing that there has been an increasing internationalization of knowledge production thanks to the interconnection between the "learning" economy and the "globalizing" economy. For Archibugi and Iammarino (2001), the development of an integrated global economy allows the acquisition of information, expertise and technology at a faster pace and often at lower costs than in the past.

However, opportunities to decentralize SIS are not yet widely explored, because information-intensive services are still concentrated in a few cities. As Rubalcaba-Bermejo and Gago-Saldaña (2002) noted, new developments in the wider division of labor are associated with a concentration of knowledge, despite the claims that new technology frees us from the constraints of special locations. This reflects the fact that a cluster is not merely a territorial agglomeration of companies, but rather presents a collective dynamics. A reliable institutional arrangement can be a key asset to create a cooperative environment, a logical pattern in the use and management of common resources and the development of interrelations (both vertical and horizontal) between companies (PIETROBELLI and RABELLOTTI, 2004).

The opportunities for development of the SIS industry vary widely across business segments. The software industry is naturally segmented between products and services. Software products are usually expensive to produce but cheap to reproduce, because information goods have high fixed costs and low marginal costs (SHAPIRO and VARIAN, 1999). Being intangible, software is characterized as a "non-rival in consumption" good, because it can be shared by users without significant additional costs caused by new entrants. This potential for knowledge diffusion, however, may be limited by intellectual property rights, which keep the majority of valuable software under the technical and economic control of a few global companies.

In some cases, proprietary software standards have generated asymmetries between software vendors, which accentuates the industry concentration trend. Access to source code, which allows the development of applications by independent companies, has been hindered by practices of vertical integration of operating systems and 
PAULO BASTOS TIGRE - RENATA LEBRE LA ROVERE - FRANCISCO LIMA TEIXEIRA - ANDRÉS LÓPEZ - DANIELA RAMOS NÉSTOR BERCOVICH - ALESSANDRO DE ORLANDO MAIA PINHEIRO - SILVIO ARAÚJO - RICARDO FURTADO RODRIGUES

applications. By building into the same package a wide range of applications that otherwise could be separately supplied by independent companies, the owner of the standard unifies and concentrates the software market.

However, not all segments of the SIS industry follow the concentration logic of the network effects. An increasingly important share of user needs is supplied through free software communities. Also, many ICT firms see software as a small portion of the "business solutions" industry. A consequence of this trend is that services, rather than products, present the greatest business potential and the lowest entry barriers for new companies.

Given that job creation must be one of the main objectives of public policies on SIS, we must bear in mind that the special nature of software products and services has important implications for employment. While global software service providers employ an average of 16.4 people per million dollars of sales in Latin American countries, corporations that supply only software products employ 2.6 people per million dollars. Since the latter bring pre-prepared packages from abroad, in practice they do not employ people locally (TIGRE and MARQUES, 2009).

Opportunities are particularly present in ICT outsourcing, which, according to Sparrow (2003), can be understood as the practice of delegating the planning, management and operation of certain functions to an independent third party, in accordance with the terms of a formal service-level agreement (SLA). The rise of software and service offshoring is enabled by changes in labor processes, including reorganization of processes in a manner that many of them can be outsourced. These factors have allowed new cities and communities to enter the global ICT service markets.

Bathelt and others (2004) suggest that successful clusters combine local knowledge production with the transfer of external codified knowledge. Most regional policies designed to attract ICT operations aim at creating local capabilities and network effects, either through inter-firm subcontracting or technological cooperation. Despite the existing differences in educational level between developed and developing countries, it can be argued that some middle-income developing countries have a larger potential for ICT outsourcing than advanced countries, since they still have opportunity to close the educational gap. Due to the demographic situation, the economically active population is growing at a slower rate in developed than in developing countries. Furthermore, most people at vocational school and/or university age are effectively already studying, in contrast with developing countries. As a result, if investments in education in developing countries grow, there might be an expansion of the share of emerging countries in the global ICT service job market.

\section{MAIN FINDINGS OF THE RESEARCH}

As mentioned in section "A review of theory: business clusters in the sis industry", policymakers may promote clusters by providing subsidies to attract large companies that will act as hubs, or by sponsoring networks of firms, fostering either Italian-style industrial districts ,or technological poles. Also, the locational decisions of firms depend on the attractiveness of the region, which is linked to its specific set of (institutional, social and human) resources. Our case studies were selected while taking these stylized facts into account, and they provide interesting clues on the locational decisions of firms, network effects and local development.

A preliminary study taken on Rio showed that in big cities the natures of the local relationships are usually hidden by technological externalities associated both to specialization and diversity, what made the three largest cities within the region - São Paulo, Rio de Janeiro and Buenos Aires - to be excluded of the research project. So, the first initial SIS clusters we proposed to be studied were Córdoba and Rosario (Argentina), Blumenau, Hortolândia, Porto Alegre, Petrópolis, Recife and Salvador (Brazil). However, Petrópolis was excluded because it has not reached the critical mass that could characterize it as a technological centre. Another SIS cluster excluded was Córdoba, which does not fit in only one of the cluster's definition found and is rather a combination of them. We then focused our analysis in this article on the remained six SIS clusters.

\section{Locational decisions: path dependence and institutional development}

Our first research question is, "Given the intangible nature of SIS activities, what are the elements that determine the attractiveness of a region to SIS firms?" We found that, in the case of Hortolândia, local operations were merely dependent on previous locational decisions made by hardware firms that shifted to software and service production. In the cases of Tecnopuc and Porto Digital, the decisions to invest in these clusters were clearly linked to the availability of qualified human resources with the relevant technical skills because of the existence of nationally renowned universities, public policies and fiscal incentives, as well as the fact that the location relied on a friendly institutional environment. Another essential 
component is related to the long-term consolidation of an institutional basis in which ICT activities are prioritized and their development occurs in a more planned and sustained manner, involving the convergence of policies and business interests.

The existence of local markets is an important factor in the genesis of some clusters, particularly when they demand services and specific developments. The case of Blumenau illustrates the way how sound institutional arrangements of SIS users can help to create locally-owned firms and strong user-producer relationships.

No cluster can aspire to play a significant role in the regional SIS industry without strongly investing in the training of human resources. The majority of clusters studied were shown to be facing growth problems due to disputes over skilled labor, especially between foreign and local companies. Since the former are able to offer better salaries and career prospects, they recruit the best workers, many of whom were trained with the support of local companies.

However, human resources are not only about quantities. There is a shortage of personnel trained not only in technical skills, but also in foreign languages and knowledge of business processes. The relative local shortage of skilled people poses a critical problem for all clusters and is highlighted by large-company officers interviewed for this project as the major hindrance to investment. Public policies aimed at attracting companies operate as a complementary driver, particularly in view of the competition between different cities.

\section{Network effects}

As far as our second research question on the transmission of technology to the local economy is concerned, the findings of the research indicate that network effects may exist in some cases, particularly when there is a technological pole engaged in high-level activities. The cases of Tecnopuc and Porto Digital show that there are some subcontracting and joint research projects between universities, multinationals and smaller firms. In Brazil, these projects receive tax rebates under the Informatics Law and probably would not occur without such incentives.

In Porto Digital, the prevailing operating model of multinationals engaged in the SIS industry has been alliances with local players, both for subcontracting services and for developing R\&D projects. This strategy was favored to a great extent by the incentives included in the Informatics Law, which fostered investment in the region, by the presence of local players with the necessary capabilities and by the development of a favorable environment through networking. This type of articulation between large international companies and local players has very positive effects on the latter in terms of technological learning and accumulation of management capacities, as well as some effect on internationalization, which has allowed local players to enter new business industries.

In Tecnopuc, the cooperative relations between the companies and the university have sought to explore advantages such as the availability of special services, infrastructure, the local knowledge base and new business opportunities via outsourcing. However, the case study also found a low propensity for cooperative projects, dependence on a single customer, and problems in staffing and contract management, among others.

The cases analyzed above show that geographical proximity between large and small SIS companies does not necessarily encourage cooperation and positive externalities. Rather, it may increase competition for the scarce skilled human resources. The evidence collected in this study shows that, outside the scope of technological poles, there is less space for subcontracting and technological cooperation. The main barrier for local subcontracting is that the SIS production chain is too short, and the entire product or service development cycle can be performed by a single firm. Also, large corporations do not resort to subcontracting because they fear losing control over undisclosed information and facing managerial problems with smaller firms. Good reputation is a key asset in the outsourcing business, and large firms tend to avoid transaction costs by internalizing the entire business cycle. They usually resort to subcontracting either to hire temporary workers or to have access to specialized knowledge which is not available within the corporation.

In Rosario, the arrival of technology companies has had a strong impact on the respective region, even though these companies do not seem to have important interrelations with the local industry. However, it is necessary to distinguish in this general situation the cases of "laborintensive" technology companies from those that can be described as "knowledge-intensive." In the first case, the entry of these companies has clearly affected the labor market and resulted in strong pressure on the salaries paid in the industry. In the second case, the arrival of these companies, which work with more "complex" segments in technological terms, tends to be more welcomed by local companies as an important contribution to the visibility of the industry at an international level and a positive factor for the improvement of the technical capabilities available in each region.

In Blumenau, there are important obstacles to a greater 
PAULO BASTOS TIGRE - RENATA LEBRE LA ROVERE - FRANCISCO LIMA TEIXEIRA - ANDRÉS LÓPEZ - DANIELA RAMOS NÉSTOR BERCOVICH · ALESSANDRO DE ORLANDO MAIA PINHEIRO - SILVIO ARAÚJO - RICARDO FURTADO RODRIGUES

articulation between large and small local companies. The latter have faced negative experiences with the allocation of labor, which ends up being directly hired by their customers. For large firms subcontracting involves problems regarding the long term and the high cost involved in familiarizing contract staff with the systems used, particularly in complex operations.

\section{Local SIS industry development perspectives}

Finally, our third research question concerns the challenges and opportunities for development, using employment generation as the main indicator. By paying better salaries, technology-intensive activities can create a demand for better-skilled workers and sustain higher growth rates in added value and employment in the long term (ARCHIBUGI and IAMMARINO, 2001).

The generation of skilled jobs is likely to be the single major benefit from offshore outsourcing. The SIS industry is characterized by the intensive use of highly skilled human resources. According to McKinsey (2005a, p. 161), $88 \%$ of workers employed by the SIS industry worldwide have complete or incomplete university education. The activity requires technical skills to operate and absorb frequent technological changes, which requires capabilities to learn continuously. The specific skills required from workers are generally associated with the technological platforms used. In outsourcing services, vendors need to be skilled in the different technologies adopted by clients. For this reason, they tend to create outsourcing centers for different types of operations. SIS companies are organizing themselves in operational modules located in different countries. IBM, for example, is developing a model that it calls "globally integrated operations," in which the company brings together professionals in Centers of Competence - groups of people with specific abilities around the world. Instead of each national business unit having a complete staff, people are virtually called to the centers of competence when required.

However, software personnel are in short supply everywhere. For example, it is estimated that there are 4.5 million Java professionals (analysts and programmers) worldwide and a shortage of two million workers that cannot be met (VALOR ECONÔMICO, 2006). In all the cases examined here, the shortage of skilled personnel is seen as the main obstacle for further development. To participate in international networks, it is not enough to know programming and systems analysis; proficiency in English and other languages is also required. This includes not just linguistic abilities per se, but also the ability to understand specific cultural codes of relationship and com- munication. Workers have to adopt the quality standards of clients, meet deadlines and inspire confidence in their partners abroad. These cultural abilities are considered to be even rarer than technical abilities.

In conclusion, the answers to the three research questions depend on the following elements: availability of skilled human resources; presence of strong universities and research centers; adequate public policies; network effects and local markets. Exhibit 1 summarizes the main results of each case study regarding these elements and groups case studies according to the taxonomy presented in section "Proposed taxonomy of software clusters".

\section{PROPOSED TAXONOMY OF SOFTWARE CLUSTERS}

The SIS cluster cases studied are not homogenous, and differences can be seen in regard to the specialization profile, target markets, institutional arrangements and the predominant type of company. In order to further clarify these differences and associate them to the strategies of companies, institutional arrangements and government policies, the software clusters analyzed here were classified into three categories. As with any taxonomy, these categories are somewhat arbitrary, but they help us to understand the types of production factors which are more critical in each case and to evaluate public policies for further development.

\section{Outsourcing platforms}

When close interactions between SIS users and suppliers are not important, there is the option to locate operations elsewhere if this represents an opportunity for lower costs, especially labor costs. In this business model, the services provided are relatively sketchy in terms of knowledge, such as the generation of code and call centers, and can be carried out on a relatively large scale. The tasks to be carried out are simple and specified by the client, which facilitates the division and outsourcing of tasks. What is important to attract SIS business in this case is the pool of skilled labor, process management capabilities and good infrastructure.

Outsourcing platforms are usually dominated by large firms which provide services to both domestic and international clients. Competitive pressures have led these companies to search new locations for their ICT operations with the aim of reducing costs and gaining access to skilled human resources. Given the possibilities of decentralization of software and service production, large SIS companies are fragmenting their operational bases, both in 
their countries of origin (inshore) and abroad (offshore).

Outsourcing platforms may be seen as "enclaves," since major firms do not need to maintain close links with regional users or suppliers. Their location may be a result of path dependency, search for new supply of skilled human resources at competitive costs and fiscal benefits. Because their production chain is very short, they usually do not search local suppliers of ICT services. Thus, knowledge diffusion through these platforms is very limited.

In Brazil, two cases involving the same corporation may illustrate the features, challenges and opportunities faced by SIS platforms. The first is Hortolândia, where IBM runs its larger Global Delivery Center in Latin America. With 7,000 employees, it is located near Campinas, in the state of São Paulo. The IBM Center in Hortolândia opened in 1971 as a computer and printer manufacturing plant, but during the 1990s the company changed the focus of its operations from hardware to software. Currently, $90 \%$ of the operations of this company are services, segmented into outsourcing services, application development and maintenance (software factory), business process outsourcing (BPO) and the Americas Delivery Center, which is in charge of monitoring all IBM units in the Americas. Managers interviewed reported that, due to increasing global demand, the site could actually double the workforce employed if there were skilled personnel available.

IBM developed, in association with municipal authorities, the Tech Town Condominium, which housed various technology companies, including a new Dell manufacturing plant. The companies share services such as transportation, security and catering, but there are few commercial relations between them in the ICT area, since they do not operate in the same production chain. IBM has training programs involving partnerships with universities which are not necessarily located in the Hortolândia region.

In search for new sources of skilled personnel, IBM has been participating in another initiative (ALTIS) to build a software cluster in Salvador for promoting support to IBM's international operations in the mainframe software segment. After being partially displaced by small-scale equipment, mainframes have recovered market share, especially because of the better price-performance relationship, flexibility of use and virtualization of servers. Because it is not economically viable to transfer applications from mainframe platforms to another type of hardware/software architecture, IBM has substantial expectations of growth in the use of this type of equipment.

ALTIS presents an alternative business model: it is a social institution, a type of cooperative, resulting of an articulation between the state government of Bahia, IBM and local professionals. In this partnership, ALTIS was responsible for assembling the infrastructure and contracting labor. IBM was the integrator of the process, with teams monitoring implementation and quality, as well as initially being the only customer. ALTIS occupied a building ceded by the government of Bahia, located in the old business center of Salvador, a location intended to become a software cluster.

Until now, ALTIS is far from reproducing the success of Hortolândia. The business plan estimated that it would generate four thousand top-level jobs within five years, but after two years of operations only one hundred jobs had been created. The main setback is the shortage of skilled people. Mainframe personnel are no longer available and,

Exhibit 1 - Summary of the main findings of the research

\begin{tabular}{|c|c|c|c|c|c|c|c|}
\hline \multirow{2}{*}{\multicolumn{2}{|c|}{ CASE/ELEMENT }} & \multicolumn{4}{|c|}{ LOCATIONAL DECISIONS DRIVERS } & \multirow{3}{*}{$\begin{array}{l}\text { NETWORK } \\
\text { EFFECTS } \\
0\end{array}$} & \multirow{3}{*}{$\begin{array}{c}\text { GROWTH } \\
\text { OF LOCAL } \\
\text { EMPLOYMENT } \\
\bullet\end{array}$} \\
\hline & & \multirow{2}{*}{$\begin{array}{c}\text { LOCAL } \\
\text { UNIVERSITIES } \\
\text { O }\end{array}$} & \multirow{2}{*}{$\begin{array}{c}\text { PUBLIC } \\
\text { POLICIES } \\
\text { D }\end{array}$} & \multirow{2}{*}{$\begin{array}{l}\text { LOCAL } \\
\text { MARKETS } \\
0\end{array}$} & \multirow{2}{*}{$\begin{array}{c}\text { PREVIOUS } \\
\text { LOCATION } \\
0\end{array}$} & & \\
\hline Outsourcing & Hortolândia & & & & & & \\
\hline platforms & Salvador & 0 & - & 0 & D & 0 & 0 \\
\hline \multirow{2}{*}{$\begin{array}{l}\text { Technology } \\
\text { clusters }\end{array}$} & Tecnopuc & 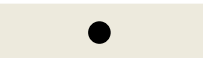 & D & 0 & 0 & $\bullet$ & - \\
\hline & Porto Digital & $\bullet$ & 0 & $\mathbf{0}$ & 0 & $\bullet$ & 0 \\
\hline \multirow{2}{*}{$\begin{array}{l}\text { User-producer } \\
\text { networks }\end{array}$} & Rosario & $\mathbf{0}$ & 0 & 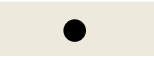 & 0 & 0 & 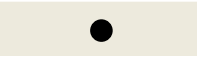 \\
\hline & Blumenau & 0 & D & ○ & D & $\mathbf{0}$ & ○ \\
\hline \multicolumn{8}{|c|}{$\begin{array}{l}\text { O Not important } \\
\text { D Relatively important } \\
\text { Very important }\end{array}$} \\
\hline
\end{tabular}


although there is a local supply of IT training courses, these are less and less sought after. There was a high level of dissatisfaction among personnel from the area with the local work market, which, despite low salaries, demands a lot from professionals. Salaries are seen as incompatible with the high level of demand, particularly in relation to fluency in English. The result is that there is a shortage of personnel which increases every year. The absence of better-structured initiatives to motivate and train human resources in an area of specialization considered by students to be less attractive (mainframes) is the primary cause of the relative failure of the initiative.

\section{Technology clusters}

In this business model, the services provided have a relatively high aggregation of knowledge, albeit on a small scale. They are characterized by the use of local technological skills and a more integrated university-business relationship in software customization, contract-based $\mathrm{R} \& \mathrm{D}$ and specialized consulting activities. Two among the clusters studied explicitly assume this status: Tecnopuc (Porto Alegre) and Porto Digital (Recife).

Tecnopuc is a Pontifical Catholic University of Rio Grande do Sul (PUC-RS) Technology Park which essentially aims at expanding research activities and job opportunities for teaching workers and students. It employs approximately 2,300 people, $40 \%$ of whom are PUC graduates or students. Currently, there are 34 companies operating in the ICT, biotechnology, energy and health areas, as well as R\&D centers. DELL was the first company to set up operations in the Park, having created the first software development unit for internal company use outside the United States. Shortly afterwards, Hewlett Packard also set up a R\&D center and a software factory there. Tecnopuc, designed as a form of integrating the activities of ICT companies and a university regarding $\mathrm{R} \& \mathrm{D}$ efforts, has also an important role in sustaining a privileged environment for generation of technological innovations. The Park has received public resources for R\&D projects and ICT training and qualification.

By setting up in Tecnopuc, companies seek to explore the availability of highly qualified human resources, technological infrastructure and services, access to the knowledge base, new business opportunities and the use of tax incentives in partnership with the university. Although the subcontracting of local companies by multinationals does occur, mainly for test-related activities, there is an intense competition for human resources which generally favors the larger companies. The supply of professionals with a postgraduate degree implies higher wages and training costs and increases the risk of loss of capacity due to high turnover.

The second technology cluster studied is Porto Digital, a successful case based on two initiatives: the first was the creation, in the late 1990s of the Recife Center for Advanced Studies (CESAR), a spin-off from the Universidade Federal de Pernambuco (UFPE) Information Technology Center, which was largely responsible for the vitality with which $R \& D$ activities were carried out in the Center. The second was the provision of physical infrastructure and tax incentives by local and national governments for companies and research centers located in the remodeled old port area. The success in the promotion of an important geographic agglomeration of companies and supporting institutions through various incentives and the provision of services facilitated the articulation between local players, circulation of information and knowledge and creation and consolidation of new companies and alliances. There are about 200 small SIS companies in the cluster, employing 3,000 people.

The quantity and quality of human resources trained in Recife explains, and is also the result of, this process. The CESAR is both the innovative core and main engine of the cluster. The connections between the CESAR and other companies and institutions in the cluster now form a network through which knowledge, businesses and new training and internationalization projects flow. The main clients of the CESAR are multinational companies engaged in the ICT area in Brazil, both in relation to the subcontracting of services and the development of R\&D projects. This relationship was favored by the Informatics Law, which provides tax incentives for R\&D activities in the Northeast Region of Brazil and would probably not succeed without this support.

\section{User-producer networks}

This business model is mainly oriented to meet regional demands which are not adequately supplied locally by global companies. Given that most ICT services require interaction between client and supplier, contracting local companies is an understandable option. SIS firms serving exclusively the regional market are usually locally-owned and have a good user-supplier relationship through the development of specific solutions for local needs. This way they contribute to technological diffusion and to increase the productivity of local industry. Among the clusters analyzed, Blumenau and Rosario are the ones that best fit this classification.

Blumenau is a mid-sized city whose economy is based on the textile and food industry. An important feature 
of Blumenau is the existence of strong institutional ties, associated with the German culture of the immigrants who founded the city in the late nineteenth century. The software industry emerged from an initiative of textile companies, which created a data processing center (CETIL) in 1969 to provide information technology services to local companies. In 1992, BLUSOFT, a technological center articulating software businesses and local supporting institutions, was created. In the last two decades, many small- and mid-sized companies have been created, particularly in the production of horizontal software. Currently, the software industry employs 5\% of the labor force and concentrates approximately $7 \%$ of software companies in Brazil. Local companies now have a national profile, and there has been a sustained growth in the number of software companies with export revenues, in the number of persons employed and in tax revenues.

A relevant event was the arrival of T-System, a German subsidiary of Volkswagen specialized in on-board software for the automobile industry. The factors that motivated the relocation of this company to Blumenau were the availability of human resources fluent in German, the region's history of software activities and the institutional support from local businesses. Although T-System has a reputation of being insular, the company has established partnerships with local companies that provide software services.

Despite its success, Blumenau suffers from the lack of highly skilled labor in light of the growth of demand, especially after the arrival of foreign companies. On the other hand, the local market is no longer sufficient to sustain growth, while expansion to other markets requires local companies to expand in size.

Rosario, Argentina, is a case that presents similarities to the user-producer network cluster. Relying on important industrial companies, an institutional and educational base (around $15 \%$ of its population have higher education), the governing philosophy of Rosario for the ICT industry has been to support the development of a favorable environment that can attract potential investors, promote synergies with local players and provide potential investors with attractive and appropriate services in order to encourage them to set up operations in the city. The government does not seem interested in converting Rosario into an export platform for services (presumably with low value-added) unless they create connections with local firms.

During this decade when the SIS market has shown great dynamism, which has encouraged the creation of many new companies, the joint work of companies, universities and the local government has accelerated. This resulted in the creation of the Rosario Technological Center (PTR), a private non-profit organization with public and private participation. One of the most important initiatives was the implementation of quality programs in software processes, as well as the rebate of a local tax to promote the SIS industry.

Rosario neither presents strong university-enterprise ties nor can be described as an outsourcing platform aimed at foreign markets. Thus, neither the city nor the province rely on a variety of subsidies or incentive to attract ICT companies. Despite that, three transnational companies (Neoris, EDS and Accenture) have set up operations in the city to take advantage of the availability of skilled human resources and an environment favorable to this type of activity. The first foreign company to set up operations in Rosario was Neoris, a company created as a technology division of Mexican cement maker Cemex, which purchased Rosario-based software company Amtec.net. EDS (which was taken over by HP in September 2009) went to Rosario because of one of its largest customers, automobile manufacturer General Motors, whose industrial complex is in the outskirts of the city. In 2006, Accenture set up a Software Development Center with approximately 200 consultants. These multinationals created opportunities for exporting services through the integration of their respective global network. However, according to interviews with officers of smaller local companies, interaction between local and foreign companies is rare and local businesses are concerned about the competition for qualified human resources.

\section{CONCLUSIONS}

The proposed taxonomy of SIS clusters shows that software firms have different needs according to their product/ service strategies, target markets and scope of operations. The types of resources required are differently balanced according to each category. We found that, in some cases, regional policies failed because the availability of human and other resources did not meet the needs of the type of business that they were targeting to attract. Exhibit 2 summarizes the main features of the proposed taxonomy.

Outsourcing Platforms support labor-intensive operations that require a large and continuous supply of university-trained personnel. For this reason, outsourcing operations are usually located in large cities that with several local educational institutions. Despite be- 
ing a small town, Hortolândia is a successful outsourcing platform because it is located within Brazil's most developed industrial area, where thousands of new technicians can be hired every year. In addition to the availability of skilled personnel, the region offers excellent transportation and communication infrastructure, relatively low cost of living and good quality of life. In contrast, Salvador is located in a less developed region with little tradition in advanced training in IT. The supply of skilled people is short in view of the increasing local demand. Despite it being an agreeable place to live and relying on generous tax incentives, a development strategy based on large scale outsourcing would hardly thrive in the short term.

Technology Clusters rely on more qualitative resources. The successful cases studied directly involved universities with strong tradition in postgraduate and advanced research. As Beaudry and Breschi (2003) have shown, clustering alone is not conducive to higher innovative performance. Governmental tax incentives and subsidies are a necessary but not sufficient condition to attract R\&D activities. It should be noted, however, that most technology clusters are showcases for government policies that, in addition to the availability of highly skilled people, depend on direct government subsidies (such as the Informatics Law in Brazil) and would not be sustainable without this kind of support.

User-Producer Networks are typical of industrial cities where clusters of specialized users provide incentives for locally-designed solutions. The cases of Rosario and Blumenau show that good institutional arrangements, such as active business associations and good local public administration may not only give rise to SIS businesses but also leverage their industrial structure and accumu- late capabilities to boost new industries. Some industrial sectors generate a demand for specialized knowledge which is not always met by multinationals and constitute market niches for local firms with good technological capabilities. However, niches are usually temporary opportunities, since the growth of the local market would attract competition from outside. Consequently, in order to survive, local SIS firms must expand their scope of operations outside the existing cluster.

The purpose of this taxonomy is to encourage further research to shed more light on the factors that drive the development of SIS clusters in specific regions and the implications of those clusters for development.

\section{NOTE OF APPRECIATION}

This article is based on the research project Desafios e oportunidades para a indústria de software e serviços no Brasil e na Argentina, funded by the Fondo IDRC de apoyo a la investigación sobre Economía del Conocimiento en América Latina y el Caribe and coordinated by FLACSO-MX (www. continentedigital.org). The authors acknowledge the excellent criticism and suggestions made by the anonymous consultants.

\section{REFERENCES}

\begin{abstract}
ARCHIBUGI, D; IAMMARINO, S. The globalization of technology and national policies. In: ARCHIBUGI, D; LUNDVALL, B. The globalizing learning economy. Oxford: Oxford University Press, 2001
\end{abstract}

BATHELT, H; MALMBERG, A; MASKELL, P. Clusters and knowledge: local buzz, global pipelines and the process of knowledge creation. Progress in Human Geography, v. 28, n. 1, p. 31-56, 2004.

\section{Exhibit 2 - Characteristics of the proposed taxonomy}

\begin{tabular}{|l|l|}
\hline $\begin{array}{l}\text { FEATURES/ } \\
\text { CLUSTER TYPE }\end{array}$ & $\begin{array}{l}\text { OUTSOURCING } \\
\text { PLATFORMS }\end{array}$ \\
\hline Critical resources & $\begin{array}{l}\text { Large supply of university- } \\
\text { trained personnel }\end{array}$ \\
\hline Typical site & Large cities (or their outskirts) \\
\hline Target markets & Global market \\
\hline Typical firms & Large multinationals \\
\hline Cases studied & $\begin{array}{l}\text { Hortolândia (SP, Brazil) and } \\
\text { Salvador (BA, Brazil) }\end{array}$ \\
\hline
\end{tabular}

\section{TECHNOLOGY}

CLUSTERS

Postgraduate and research institutions

Cities with technical-oriented universities

Large MNs

Large MNs and locally-owned

SME

Tecnopuc (Porto Alegre, BR) and Porto Digital (Recife, BR)
USER-PRODUCER

NETWORKS

Good local institutional arrangements

Specialized industrial clusters

Local firms, market niches

Specialized firms

Rosario (Argentina) and

Blumenau (SC, Brazil) 
BEAUDRY, C; BRESCHI, S. Are firms in clusters really more innovative? Economics of Innovation and New Technology, v. 12, n. 4, p. 325-342, 2003.

CHUDNOVSKY, D; LOPEZ, A. The software and services sector in Argentina: the pros and cons of an inward-oriented development strategy. Journal of IT for Development, v. 11, n. 1, p. 59-75, 2005

COHENDET, P; JOLY, P. The production of technological knowledge: new issues in a learning economy. In: ARCHIBUGI, D; LUNDVALL, B. The globalizing learning economy. Oxford: Oxford University Press, 2001.

ERNST, D. Global production networks in East Asia's electronics industry and upgrading perspectives in Malaysia. Honolulu, Economics Series, No. 44, HI: East-West-Center Working Paper, 2002.

DESROCHERS, P; HOSPERS, G. J. Cities and the economic development of nations: an essay on Jane Jacobs'contribution to economic theory. Canadian Journal of Regional Science, v. 30, n. 1, p. 115-130, 2007.

GLAESER, E. L; KALLAL, H. D; SCHEIKMAN, J. A; SHLEIFER, A.Growth in cities. Journal of Political Economy, v. 100, n. 6, p. 1126-1152, 1992.

LÓPEZ, A. (Coord). Complementación productiva en la industria del software en los países del MERCOSUR: impulsando la integración regional para participar en el mercado global. RED MERCOSUR/Swiss Agency for Development and Cooperation, 2007.

LÓPEZ, A; RAMOS, D. Argentina: nuevas estrategias empresarias en un modelo más abierto. In: TIGRE, P; MARQUES, F. Desafios y oportunidades de la industria de software para América Latina. Mayol Ediciones/CEPAL, 2009.

LÓPEZ, A; RAMOS, D. La industria de software y servicios informáticos argentina. Tendencias, factores de competitividad y clusters. CENIT, DT 31, Nov. 2008.

MCKINSEY GLOBAL INSTITUTE. The emerging global labor market: part I - The demand for offshore. San Francisco: Talent in Services, 2005a.

MEYER-STAMER, J. Competitividad sistémica. Competitividad internacional de las empresas y políticas requeridas (Klaus Esser / Wolfgang Hillebrand / Dirk Messner / Jörg Meyer-Stamer). Berlim: Instituto Alemán de Desarrollo, 1994.

MIOZZO, M; MILES, I. The relation between the internationalization of services and the process of innovation: a research agenda. In: MIOZZO, M; MILES, I. Internationalization, technology and aervices. Prest/Cric Studies in Science, Technology and Innovation. Edward Elgar, 2002.

PACI, R; USAI, S. Externalities, knowledge spillovers and the spatial distribution of innovation. Geojournal, v. 4, 2000.

PANNE, G. V. D. Agglomeration externalities: Marshall versus Jacobs. Journal of Evolutionary Economics, v. 14, n. 5, p. 593-604, 2004
PIETROBELLI, C; RABELOTTI, R. Upgrading in clusters and value chains in Latin America: the role of policies. Sustainable Development Department, Inter-American Development Bank, Washington DC, Best Practices Available at: http://www.iadb.org/sds/mic. Acess on: 13.12.2010.

ROVERE, R. L. L; HASENCLEVER, L; ERBER, F. S. Industrial and technology policy for regional development: promoting clusters in Brazil. In: The International Journal of Technology Management and Sustainable Development, v. 2, n. 3, p. 205-217, 2004.

RUBALCABA-BERMEJO, L; GAGO-SALDAÑA, D. National versus international effects in regional concentration of European innovative business services. In: MIOZZO, M; MILES, I. Internationalization, technology and services. Prest/Cric Studies in Science, Technology and Innovation. Edward Elgar, 2002.

SCHUMPETER, J. Capitalism, socialism and democracy. New York: Harper and Brothers. 5th ed. London: George Allen and Unwin, 1976.

SHAPIRO, C; VARIAN, H. Information rules: a strategic guide to the network economy. Massachusetts: HBS Press, 1999.

SPARROW, E. Successful IT outsourcing: from choosing a provider to managing the project. London: Springer-Verlag, 2003.

TIGRE, P B. Perspectivas de cooperação Brasil-Argentina nas tecnologias de informação. In: I Seminário Brasil-Argentina - Instituto de Pesquisa de Relações Internacionais, Fundação Alexandre Gusmão. Rio de Janeiro, v .1, p. 1-24, 1999 .

TIGRE, P. B. E-commerce in Brazil: local adaptation of global technology. International Journal of Eletronic Commerce Business Media, v. 1, p. 1-10 2003

TIGRE, P. B; MARQUES, F S. La industria del software en Brasil: un mercado interno fuerte puede promover las exportaciones? Comercio Exterior Revista de Analisis Economico y Social, v. 58, n. 5, p. 350-366, 2008.

TIGRE, P. B; MARQUES, F S. Desafíos y oportunidades de la industria del software em América Latina. Colombia: CEPAL/Mayol Ediciones, 2009.

TIGRE, P. B; LA ROVERE, R; TEIXEIRA, F; LÓPEZ, A; RAMOS, D; BERCOVICH, N. Outsourcing y clusters de software en Argentina y Brasil. México: Centro Internacional de Investigaciones para el Desarrollo, 2009.

ZIMMY, Z; MALLAMPALLY, P. Internationalization of services: are the modes changing? In MIOZZO, M; MILES, I. Internationalization, Technology and Services. Prest/Cric Studies in Science, Technology and Innovation. Edward Elgar, 2002. 